\title{
光ディラックコーンの原理と応用
}

\author{
迫田和彰 \\ 物質・材料研究機構 ( ₹305-0044 茨城県つくば市並木1-1)
}

\section{Principle and Application of Photonic Dirac Cones}

\author{
Kazuaki SAKODA \\ National Institute for Materials Science, 1-1 Namiki, Tsukuba, Ibaraki 305-0044
}

(Received September 21, 2015)

\begin{abstract}
Dirac cones on the $\Gamma$ point of periodic metamaterials have a unique feature in which the electromagnetic wave propagates in the medium without a phase change, which realizes such novel optical phenomena as cloaking, scatter-free waveguides, and the lenses of arbitrary shapes. In this article, we analyze the mechanism of Dirac-cone formation by tight binding approximation and $\mathrm{k} \cdot \mathrm{p}$ perturbation to show that its essence is the accidental degeneracy of two modes with particular symmetry combinations. The Dirac cone can be materialized for any waves in the periodic structures, which include electromagnetic, electronic, phonon, and magnon waves.
\end{abstract}

Key Words: Dirac cone, Metamaterial, Photonic crystal

1. はじめに

メタマテリアルを用いて負の屈折率が実現できること はよく知られている。 これに加えて, 周期構造から成る メタマテリアルでは実効屈折率をゼロにすることもでき る.この現象は, 波数空間の原点 ( $\Gamma$ 点)に, 等方的で直 線的な分散関係(すなわちディラックコーン)を形成する ことで達成される。

構造の周期性によって電磁波の分散曲線は第1ブリル アンゾーンの内側に折りたたまれる。この結果, 「点に は無限個の電磁モードが存在する. 波数を $k$, 角振動数 を $\omega$, 真空中の光速を $c$ とて, $n_{\mathrm{eff}}=c k / \omega て ゙$ 定義される 実効屈折率 $n_{\mathrm{eff}}$ を考えると, $\Gamma$ 点 $(k=0)$ の固有モード $(\omega \neq$ $0)$ では $n_{\mathrm{eff}}=0$ である. しかし, 次節以降で詳しく述べる ように，「点では通常，電磁波の群速度がゼロであって エネルギーを運ぶことができないので，ゼロ屈折率を積 極的に利用することはできない.ところが，特定の空間 対称性をもつ2つのモードの周波数を一致させると, 群 速度が非ゼロになり， $n_{\mathrm{eff}}=0$ のメタマテリアル中を電磁 波が伝搬できるようになる.

本稿では，このようなディラックコーン形成の原理を 解説する.

\section{2. 時間反転対称性と分散関係の対称性}

本稿では，周期構造体の中を伝搬する電磁波を考察す るので, 比誘電率 $(\varepsilon)$ は位置 $(\boldsymbol{r})$ の周期関数であると仮定
する。

$$
\varepsilon\left(\boldsymbol{r}+\boldsymbol{a}_{\mathrm{i}}\right)=\varepsilon(\boldsymbol{r})
$$

$\boldsymbol{a}_{\mathrm{i}}$ は周期性を表す基本格子ベクトルで, 試料構造の次元 性に応じてiは1〜3までの值を取る。磁性体は扱わない ので比透磁率は 1 とする.

さて, マックスウェル方程式から電場を消去して, 磁 場 $(\boldsymbol{H})$ の満たす波動方程式を求めると次式を得る.

$$
\nabla \times\left[\frac{1}{\varepsilon(\boldsymbol{r})} \nabla \times \boldsymbol{H}(\boldsymbol{r}, t)\right]=-\frac{1}{c^{2}} \frac{\partial^{2}}{\partial t^{2}} \boldsymbol{H}(\boldsymbol{r}, t)
$$

この微分方程式は時間について2階なので，時間の向き を逆にしても $(t$ を $t$ にしても)方程式は不変である。し たがって, 電磁場の固有モードの波数ベクトルをkと記 すと, $\boldsymbol{k}$ 方向に進む波と, 時間を逆転して $\boldsymbol{k}$ 方向に進む 波は同じ固有振動数をもつ。すなわち,

$$
\omega(\boldsymbol{k})=\omega(-\boldsymbol{k})
$$

つまり， $\omega$ は $\boldsymbol{k}$ の偶関数である。 それで，例えば $x$ 軸の方 向に周期的な構造物を考えて, $x$ 軸方向の波数を $k_{\mathrm{x}}$ と記 し, 原点の周りで $\omega$ をテイラー展開すれば, $k_{\mathrm{x}}$ の奇数次 の項は存在しない.

$$
\omega\left(k_{\mathrm{x}}\right)=\omega(0)+f_{2} k_{\mathrm{x}}^{2}+f_{4} k_{\mathrm{x}}^{4}+\cdots
$$


したがって, 原点のごく近くでは分散曲線は二次曲線で あり，傾きは水平であると結論できる，実際，多くの場 合にそのような分散曲線が観測される。（ただし， $\omega=0$ の場合を除く.)

しかし，㛜密に言うとこの議論は正しくない. Fig. 1 に示すように，2本の分散曲線が原点上で交わる場合， 両者の傾きの絶対值が等しく，符号が反対であれば,

(3) 式を満たしつつ, $k_{\mathrm{x}}$ の一次の項が存在し得る。本稿 の主たる目的は，このような線形の分散関係が生じる必 要十分条件を見出すことである.

生成の条件の導出は第3節以降で行うこととして, こ こではまず，そのような分散曲線が生じた場合に期待さ れる，新奇な光学現象について考察してみよう。改めて 波数を $k$ と記し, 交点の角振動数を $\omega_{\Gamma}$, 傾きを $v$ と記す と,

$$
\omega-\omega_{\Gamma}=v k
$$

の関係がある. $v$ は $\omega$ をで微分したときの微係数だから 群速度 (波束の伝搬速度)である。他方，単位構造よりも 十分大きなスケールで電磁場を粗視化したときに，系の 電磁応答が実効屈折率 $n_{\mathrm{eff}}$ でよく記述できると仮定する と, 一様な誘電体の分散関係と同じ形の関係式が満たさ れるべきであるから，

$$
\omega=\frac{c}{n_{\text {eff }}} k
$$

である，一見すると，(5)式と（6)式は両立しないように 見えるが，実は，

$$
n_{\mathrm{eff}}=\frac{c}{\omega_{\Gamma} v}\left(\omega-\omega_{\Gamma}\right)
$$

であれば, $\omega \equiv \omega_{\Gamma}$ の近くでは(5)式と(6) 式が一致して, 両立する。（7)式から， $\omega$ が $\omega_{\Gamma}$ に近づくにつれて有効屈 折率は小さくなり， $\omega=\omega_{\Gamma}$ でゼロになる.

電磁波の位相 $\phi$,

$$
\phi=\omega\left(t-\frac{n_{\mathrm{eff}} x}{c}\right)
$$

で与えられるので, $k=0$ では有限の群速度 $v て ゙$ 電磁エネ ルギーが伝わっているにもかかわらず, 空間的な位相変 化が無いという奇妙な性質を示す。この性質を用いて,

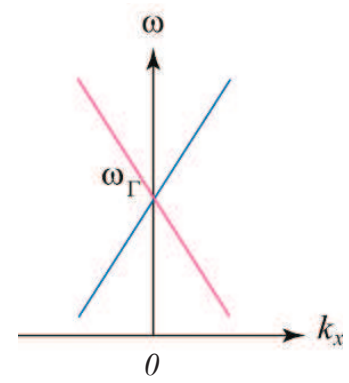

Fig. 1 Linear dispersion relation at the origin.
クローキング(透明マント)や鋭く曲がった屈曲導波路, 任意形状のレンズなどを実現できることが数值シミュ レーションで示された1).

\section{3. 強結合近似による解析}

ディラックコーンの生成条件を直感的に説明するため に，まず，強結合近似による導出について述べる。例と して，Fig. 2に示す1次元周期構造について考えてみよ う。これはマイクロ波の漏れ波アンテナとして設計され た構造で， $k=0$ で線形な分散関係が達成された ${ }^{2}$ 。誘電 体の板の上面にはFig. 2(b)に示すような形状の電極が周 期的に並べてあり，裏面は薄い平板電極で一様に覆われ ている。

単位構造について電磁モードを数值計算で調べてみる と，関係する周波数範囲にFig. 3に示すような，2つの共 鳴モードが存在することが分かった ${ }^{3)}$. 単位構造が $\mathrm{C}_{2 \mathrm{v}}$ (長方形と同じ)対称性をもつことを反映して，共鳴状態 も一定の空間対称性をもつ. $\mathrm{A}_{1}$ モードは $x z$ 面と $y z$ 面での 鏡映について対象であり, $\mathrm{B}_{1}$ モードは $x z$ 面については対 称， $y z$ 面については反対称である。

さて，2つの共鳴モードが単位構造に強く局在してい るので，周期構造の分散関係の計算では，これら2つの 共鳴状態を基底関数に用いた強束縛近似が良い近似解を 与えると期待できる.

そこで，2つの共鳴状態の磁場関数 $\boldsymbol{H}_{0}^{(1)}$ と $\boldsymbol{H}_{0}^{(2)}$ を用い て, ブロッホの定理を満たす波数 $k$ の固有モードの磁場 を次にように表す。

$$
\boldsymbol{H}_{\mathrm{k}}(\boldsymbol{r})=\frac{1}{N} \sum_{n=-N / 2}^{N / 2-1} e^{\mathrm{ikna}}\left\{A \boldsymbol{H}_{0}^{(1)}(\boldsymbol{r}-n \boldsymbol{a})+B \boldsymbol{H}_{0}^{(2)}(\boldsymbol{r}-n \boldsymbol{a})\right\}
$$

ここに, $k$ はブリルアンゾーン $([-\pi /|\boldsymbol{a}|, \pi /|\boldsymbol{a}|])$ 内の波数, $a$ は基本格子ベクトル， $n$ は整数， $N$ は周期的境界条件を 課す単位構造の総数で, 偶数であるとした。 さて, ここ

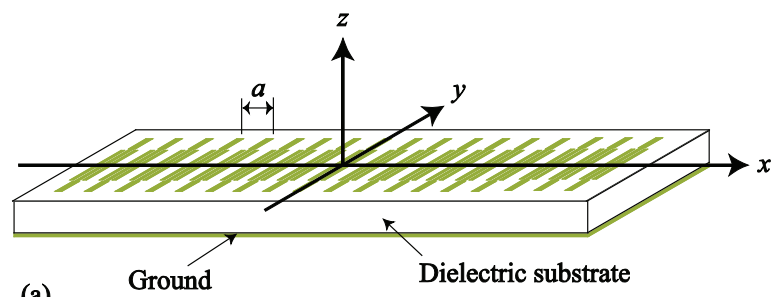

(a)

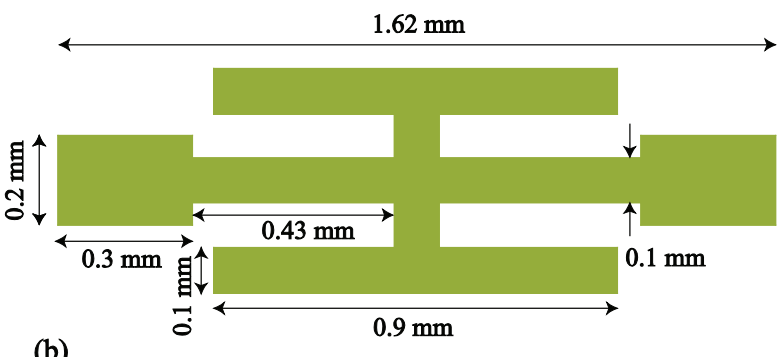

Fig. 2 (a) The structure of a leaky antenna that materializes a linear dispersion. (b) The shape of the metallic unit structure $^{3)}$. 
で $\boldsymbol{H}_{\mathrm{k}}$ の対称性について考えてみよう。点群 $\mathrm{C}_{2 \mathrm{v}}$ に含まれ る対称操作は,

E 恒等変換

$\mathrm{C}_{2} z$ 軸周りの 180 度回転

$\sigma_{\mathrm{x}} y z$ 面に関する鏡映

$\sigma_{\mathrm{y}} x z$ 面に関する鏡映

の4つである。 $\mathrm{k} \neq 0$ の場合 ${ }^{4}, \mathrm{C}_{2}$ と $\sigma_{\mathrm{x}}$ は $k$ を $-k$ に変換する ので, 対称操作後の関数は波数 $k$ の固有モードではなく なってしまう。したがって, $\boldsymbol{H}_{\mathrm{k}}$ は $\mathrm{C}_{2}$ と $\sigma_{\mathrm{x}}$ に関してはいか なる対称性も示さない. これに対して， $\sigma_{\mathrm{y}}$ は $k$ を不変に 保つ. また，2つの基底関数も $\sigma_{\mathrm{y}}$ に関して一定の対称性 をもつ(Fig. 3の例ではともに対称). したがって， $\boldsymbol{H}_{\mathrm{k}}$ を $\sigma_{\mathrm{y}}$ に関して，また当然のことであるが恒等変換Eに関し ても, 一定の対称性をもつ. $\left\{\mathrm{E}, \sigma_{\mathrm{y}}\right\}$ のつの対称操作か ら成る点群を $\mathrm{C}_{\mathrm{s}}$ と呼ぶ。 上で述べた事情を群論の用語で 言うと， $\boldsymbol{H}_{\mathrm{k} \neq 0}$ は $\mathrm{C}_{\mathrm{s}}$ の既約表現である. $k=0$ の場合は特殊 である. $k(=0)$ は $\mathrm{C}_{2 \mathrm{v}}$ のすべての対称操作のもとで不変 であるので, 変換後の $\boldsymbol{H}_{\mathrm{k}=0} も \mathrm{C}_{2 \mathrm{v}}$ のすべての対称操作に 関して一定の対称性をもたなければならない. 群論の用 語で言えば, $\boldsymbol{H}_{\mathrm{k}=0}$ は $\mathrm{C}_{2 \mathrm{v}}$ の既約表現である。

さて，(9)式に戻ろう。基底関数が2つあるので，(9) 式を波動方程式 ((2) 式)に代入してそれぞれの波数kにつ いて固有值方程式を解けば, 2つの固有值と固有関数が 得られる。すなわち，2本の分散曲線が得られる (Fig. 4 参照). 試料構造を調節することで, Г点(波数空間の原 点)の固有值を互いに一致させることができる ${ }^{3)}$.

Г点では, 2つの基底関数の対称性が異なるので, 固 有モードの形成の際に両者は混じり合わない。すなわ ち, 混じり合ってしまうと $\mathrm{C}_{2 \mathrm{v}}$ に固有な対称性をもたな くなってしまう。これに対して, $\mathrm{k} \neq 0$ については4), 2つ の基底関数がともに $\sigma_{\mathrm{y}}$ に関して対称な関数なので, 固有 モードの形成の際に両者は混じり合うことができる。す
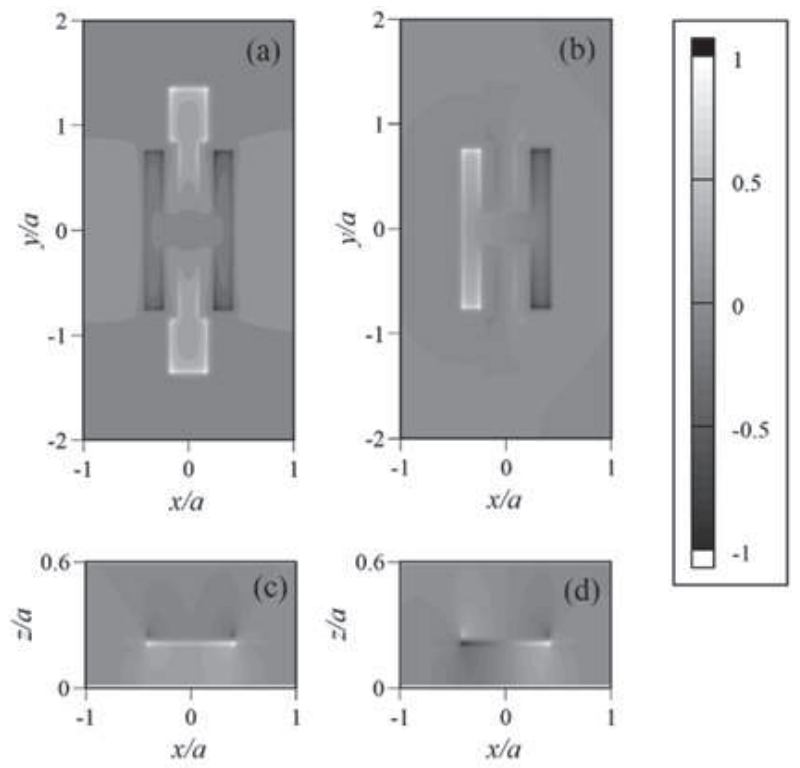

$\mathrm{A}_{1}$ mode

(82.8 GHz)
$B_{1}$ mode

(96.6 GHz)

Fig. $3 H_{z}$ of two resonance modes in the unit structure ${ }^{3)}$.

なわち，2つのバンドともの箳して対称な固有モード である(Fig. 4ではAと記した)。一般に，波動関数が混 じり合うと固有值が互いに反発する性質があり，これを 反交差と呼ぶ.

以上をまとめると，「点ではモードの対称性が異なる ために基底関数が混じり合わず，固有值が互いをすり抜 ける(交差する)．「点以外では対称性が等しいために基 底関数が混じり合って, 固有值が反交差する。この交差 と反交差のバランスによって，Г点の固有值が一致する 場合には，「点近傍で線形の分散関係が得られる (Fig. 4 (b) 参照) $)^{3)}$.

つぎに，周期構造の次元を $1 つ$ 上げて，2次元の場合を 見てみよう. Fig. 5は正方形と同じ対称性 $\left(\mathrm{C}_{4 \mathrm{v}}\right)$ の電極を 上面にもつ2次元正方格子である. 点群 $\mathrm{C}_{4 \mathrm{v}}$ は $\mathrm{C}_{2 \mathrm{v}}$ よりも対 称性が高いので, その分, 固有モードの空間対称性も多 彩である。特に， $\mathrm{C}_{2 \mathrm{v}}$ には見られなかった，2重縮退した
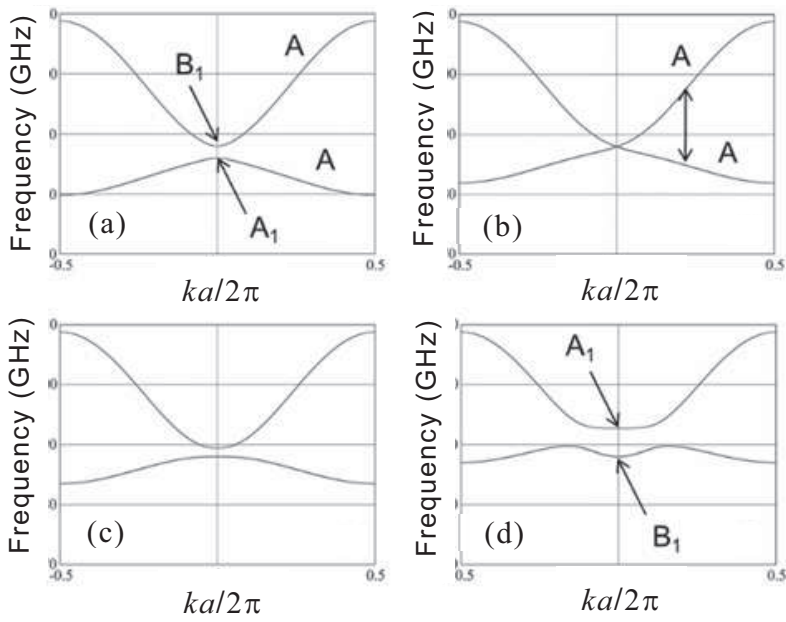

Fig. 4 Changes in the shapes of two dispersion curves for (a) positive, (b) zero, (c) negative, and (d) large negative band offset. The horizontal axis is the wave number in the Brillouin zone and the vertical axis is the frequency in $\mathrm{GHz}^{3)}$.
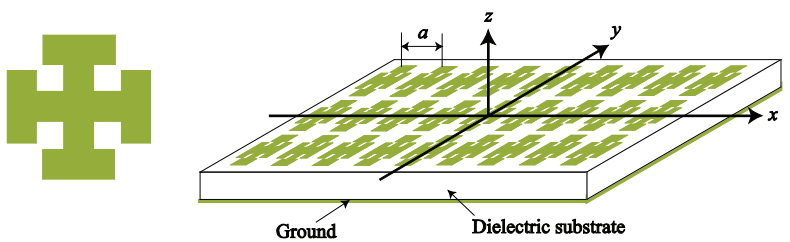

Fig. 5 (Right) The structure of a two-dimensional leaky antenna that consists of a regular square array of unit cells. (Left) The shape of the metallic unit structure ${ }^{5)}$.

Table 1 Symmetry of eigen modes on the $\Gamma$ point.

\begin{tabular}{|c|c|c|c|c|c|c|c|}
\hline $\mathrm{C}_{4 v}$ & Basic & $\sigma_{\mathrm{y}}$ & $\sigma_{\mathrm{x}}$ & $\mathrm{C}_{6 v}$ & Basic & $\sigma_{\mathrm{y}}$ & $\sigma_{\mathrm{x}}$ \\
\hline$A_{1}:$ & $\mathrm{H}^{(0)}$ & +1 & +1 & \multirow[t]{2}{*}{$E_{1}:$} & $\mathrm{H}^{(1)}$ & +1 & -1 \\
\hline \multirow[t]{3}{*}{$E$ : } & $\mathrm{H}^{(1)}$ & +1 & -1 & & $\mathrm{H}^{(2)}$ & -1 & +1 \\
\hline & $\mathrm{H}^{(2)}$ & -1 & +1 & \multirow[t]{2}{*}{$E_{2}:$} & $\mathrm{H}^{(3)}$ & -1 & -1 \\
\hline & & & & & $\mathrm{H}^{(4)}$ & +1 & +1 \\
\hline
\end{tabular}


モード (Eモード)が存在する (Table. 1). これと全対称な $\mathrm{A}_{1}$ モードが「点上で固有周波数が一致する (以下では「縮 退する」と記す) と線形で等方的な分散関係(ディラック コーン)が出現する $(\text { Fig. 6 })^{5)}$. その事情を $\mathrm{C}_{2 \mathrm{v}}$ の場合にな らって考えてみよう。

$k_{\mathrm{x}}$ 軸上では $\mathrm{C}_{2 \mathrm{v}}$ の場合と同様に $\sigma_{\mathrm{y}}$ 鏡映が定義される。 $\mathrm{A}_{1}$ モードとEモードの1つ目の固有関数が $\sigma_{\mathrm{y}}$ について対称な ので, 固有值が近づくと波動関数が混じり合って両者は 反交差する. Eモードの2つ目の固有関数は対称性が異 なるので混じり合わず，固有值は交差する（互いをすり 抜ける)。一方， $k_{\mathrm{y}}$ 軸上では， $\sigma_{\mathrm{x}}$ 鏡映が定義されて， $k_{\mathrm{x}}$ 軸 上とは逆の組合せで交差と反交差が生じる。いずれにし

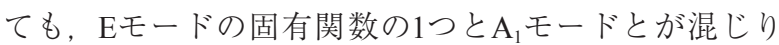
合うので，いずれの方向についても線形の分散関係が生 じる.このようにして等方的で線形なディラックコーン が生じる.

正六角形と同じ対称性 $\left(\mathrm{C}_{6 \mathrm{v}}\right)$ をもつ単位構造を3角格子 に配列した場合には，さらに面白い状況が生まれる，点 群 $\mathrm{C}_{6 \mathrm{v}}$ は $\mathrm{C}_{4 \mathrm{v}}$ よりもさらに多くの対称操作を含むので, 2種 類の2次元表現 $\left(\mathrm{E}_{1}\right.$ と $\left.\mathrm{E}_{2}\right)$ が存在する (Table. 1)。 $\sigma_{\mathrm{y}}$ につい て見ると，2組の固有関数が同じ対称性をもつ， $\sigma_{\mathrm{x}}$ につ いても組合せが異なるものの, やはり2組の固有関数が 同じ対称性である。したがって， $k_{\mathrm{x}}$ 軸上， $k_{\mathrm{y}}$ 軸上のいず れにおいても，2組のモードが互いに反交差するので, 全く同じ形状のディラックコーンが2組生成する ${ }^{6)}$ 。こ れを2重ディラックコーンと呼ぶことにする。

立方体と同じ対称性 $\left(\mathrm{O}_{\mathrm{h}}\right)$ をもつ周期構造についても 上記と同様の解析が可能で，ディラックコーンの存在が 示された ${ }^{5)}$ 。このように, 強結合近似を用いることで比 較的容易にディラックコーンの生成を示すことができ, 直感的に分かり易い説明が可能である。しかし，2次元 系や3次元系の場合, 強結合近似による解析計算は単純 ではあるが，計算量が膨大になる場合もあり，解析計算 だけですべてのモードの対称性を検討し尽くすことがで きない，また，誘電体から成るフォトニック結晶のよう に，明瞭な共鳴状態が存在しない系を取り扱うこともで きない，そこで，次節では共鳴状態を仮定しない, さら に一般的で汎用性の高い解析方法について述べる.
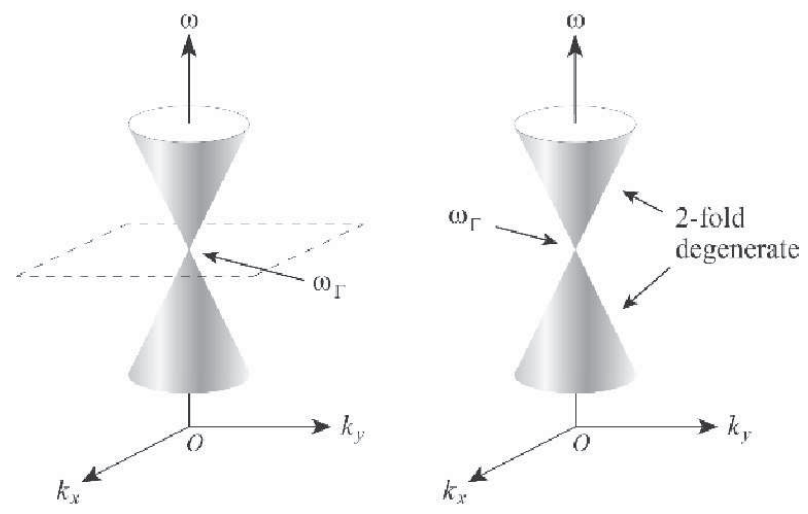

Fig. 6 (Left) Dirac cone with an auxiliary dispersion surface and (right) double Dirac cone.

\section{4. $\boldsymbol{k} \cdot \boldsymbol{p}$ 摂動法による解析 ${ }^{7)}$}

固有値問題を解く都合から, 誘電率 $\varepsilon(\boldsymbol{r})$ は実数と仮定

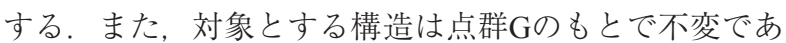
ると仮定する。磁場の固有值方程式は,

$$
L \boldsymbol{H}_{\mathrm{kn}} \equiv \nabla \times\left[\frac{1}{\varepsilon(\boldsymbol{r})} \nabla \times \boldsymbol{H}_{\mathrm{kn}}\right]=\lambda_{\mathrm{kn}} \boldsymbol{H}_{\mathrm{kn}}
$$

で与えられ，固有值は

$$
\lambda_{\mathrm{kn}}=\frac{\omega_{\mathrm{kn}}^{2}}{c^{2}}
$$

である。演算子 $L$ は $(10)$ 式の1つ目の等号で定義され る. 扱う系の周期性から固有関数はブロッホ関数であ る.

$$
\begin{gathered}
\boldsymbol{H}_{\mathrm{kn}}(\boldsymbol{r}) \equiv \mathrm{e}^{\mathrm{ik} \cdot \mathrm{r}} \boldsymbol{u}_{\mathrm{kn}}(\boldsymbol{r}) \\
\boldsymbol{u}_{\mathrm{kn}}(\boldsymbol{r}+\boldsymbol{a})=\boldsymbol{u}_{\mathrm{kn}}(\boldsymbol{r})
\end{gathered}
$$

さて， $\boldsymbol{k}$ 毎に新しい演算子 $L_{k}$ を次式で定義する.

$$
L_{\mathbf{k}} \equiv e^{-i \mathbf{k} \cdot \mathbf{r}} L e^{i \mathbf{k} \cdot \mathbf{r}}=(\nabla+i \boldsymbol{k}) \times\left[\frac{1}{\varepsilon(\boldsymbol{r})}(\nabla+i \boldsymbol{k}) \times\right]
$$

$L_{\mathrm{k}}$ はエルミート演算子で, $L$ と同じく固有值は $\lambda_{\mathrm{kn}}$ であ る.

$$
L_{\mathrm{k}} \boldsymbol{u}_{\mathrm{kn}}=\lambda_{\mathrm{kn}} \boldsymbol{u}_{\mathrm{kn}}
$$

我々に興味があるのはГ点 $(\boldsymbol{k}=0)$ 近傍の分散関係の形状 だから，固有值問題を $\boldsymbol{k}$ に関する摂動計算で解く。そこ で， $\boldsymbol{k}$ の1次までの摂動演算子 $\Delta L_{\mathrm{k}}$ を導入して,

$$
\begin{aligned}
& \Delta L_{\mathbf{k}} \equiv L_{\mathbf{k}}-L_{\mathbf{0}} \approx \Delta L_{\mathbf{k}}^{(1)}+\Delta L_{\mathbf{k}}^{(2)} \\
& \Delta L_{\mathbf{k}}^{(1)}=i \boldsymbol{k} \times\left[\frac{1}{\varepsilon(\boldsymbol{r})} \nabla \times\right] \\
& \Delta L_{\mathbf{k}}^{(2)}=\nabla \times\left[\frac{1}{\varepsilon(\boldsymbol{r})} i \boldsymbol{k} \times\right]
\end{aligned}
$$

その固有值を調べることにする。我々は2つのバンドが 偶然縮退する状況を考えるので，縮退摂動論を用いる必 要がある。すなわち， Г点上のM個の固有関数 $\left\{\boldsymbol{u}_{0 \mathrm{i}} \mid i=1\right.$ $\sim \mathrm{M}\}$ が同じ固有值 $\lambda_{0}$ をつとして, 次の行列

$$
C_{\mathrm{ij}}^{(\mathbf{k})}=\left\langle\boldsymbol{u}_{0 \mathrm{i}}\left|\Delta L_{\mathrm{k}}\right| \boldsymbol{u}_{0 \mathrm{j}}\right\rangle_{0}=i \boldsymbol{k} \cdot\left(-\boldsymbol{P}_{\mathrm{ij}}+\boldsymbol{P}_{\mathrm{ij}}^{*}\right)
$$

の固有值を $\boldsymbol{k}$ の関数として計算すれば，「点近傍の分散 関係が求まる。 $\boldsymbol{u}_{0 \mathrm{i}}$ が点群 $\mathrm{G}$ の既約表現であることを用い ると， 


$$
\begin{aligned}
\boldsymbol{k} \cdot \boldsymbol{P}_{\mathrm{ij}} & =\frac{1}{V_{0}} \boldsymbol{k} \cdot \int_{V_{0}} d \boldsymbol{r} \boldsymbol{u}_{0 \mathrm{i}}^{*}(\boldsymbol{r}) \times\left[\frac{1}{\varepsilon(\boldsymbol{r})} \nabla \times \boldsymbol{u}_{0 j}(\boldsymbol{r})\right] \\
& \equiv \boldsymbol{k} \cdot\left\langle\boldsymbol{u}_{0 \mathrm{i}}|\Delta L| \boldsymbol{u}_{0 \mathrm{i}}\right\rangle_{0} \\
& =(\mathrm{R} \boldsymbol{k}) \cdot\left\langle R \boldsymbol{u}_{0 \mathrm{i}}|\Delta L| R \boldsymbol{u}_{0 \mathrm{i}}\right\rangle_{0}
\end{aligned}
$$

が証明できる。ここで，Rは点群 $\mathrm{G}$ に属する対称操作で あり， RはRの行列表現である。（20）式を見ると， $\mathrm{k}$, $\boldsymbol{u}_{0 \mathrm{i}}, \boldsymbol{u}_{0 \mathrm{j}}$ の積がすべての対称操作 $R$ のもとで不変であるこ と，すなわち，Gの全対称表現でなければならないこと が分かる，不変でない場合は, 最右辺は恒等的にゼロで なければならず, 摂動行列Cがゼロ行列となることから 固有值もゼロである。したがって, Г点近傍の分散関係 には波数kに比例する成分が存在しないので，ディラッ クコーンも存在しない. よって, (20)式の最右辺が全対 称表現を含むことが, ディラックコーンが存在するため の必要条件である。この判別は群論の標準的な問題であ り, どのような対称性の $\boldsymbol{u}_{0 \mathrm{i}}$ と $\boldsymbol{u}_{0 \mathrm{j}}$ の組合せが全対称表現 を与えるかは，いわゆる簡約の手法を用いて調べること ができる。さらに，(20)式は行列Cの異なる要素間に多 くの関係式を与えるので, 以下で例を示すように, 行列 Cの形をほとんど一意的に決定する。このことを利用し て，ディラックコーンの生成の有無を解析計算だけで完 全に判別することができる.

\section{【例1】 $\mathrm{C}_{4 \mathrm{v}}$ 対称な2次元正方格子}

Table. 2に偶然縮退する2つのモードの対称性と生成す

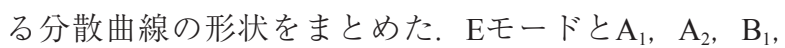
または, $\mathrm{B}_{2}$ モードの組合せだけが非ゼロの行列 $\mathrm{C}$ 与 え，その他の組合せではCはゼロ行列である。

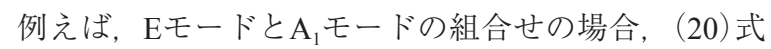
を用いることで行列Cが以下の構造をもつことが証明で きる。

$$
C_{\mathrm{k}}^{\left(E A_{1}\right)}=\left(\begin{array}{ccc}
0 & 0 & b k_{\mathrm{x}} \\
0 & 0 & b k_{\mathrm{y}} \\
b^{*} k_{\mathrm{x}} & b^{*} k_{\mathrm{y}} & 0
\end{array}\right)
$$

ここにbは $(20)$ 式に現れた $\Delta L$ の行列要素である。この表 式から分かるように，非対角項は $\boldsymbol{k} \neq 0$ のときだけ非ゼロ

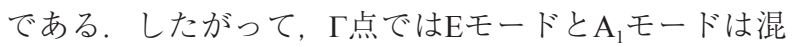
じり合わず，Г点以外では両者が混じり合って反交差が 生じる。（21)式を対角化して固有值を求めると,

Table 2 Mode symmetries and shapes of dispersion curves for a two-dimensional square lattice of $\mathrm{C}_{4 \mathrm{v}}$ symmetry. D: Dirac cone, Q: quadratic dispersion surface. ${ }^{7)}$

\begin{tabular}{ccccc}
\hline Mode1 & \multicolumn{3}{c}{ Mode2 } & Dispersion \\
\hline$E$ & $A_{1}$, & $A_{2}, B_{1}, B_{2}$ & $\mathrm{D}+\mathrm{Q}$ \\
$A_{1}, \quad A_{2}, \quad B_{1}, \quad B_{2}$ & $A_{1}$, & $A_{2}, \quad B_{1}, B_{2}$ & $2 \mathrm{Q}$ \\
$E$ & \multicolumn{2}{c}{$E$} & $4 \mathrm{Q}$ \\
\hline
\end{tabular}

Table 3 Mode symmetries and shapes of dispersion curves for a two-dimensional triangular lattice of $\mathrm{C}_{6 \mathrm{v}}$ symmetry. DD: double Dirac cone. ${ }^{7)}$

\begin{tabular}{ccc}
\hline Mode1 & Mode2 & Dispersion \\
\hline$E_{1}$ & $E_{2}$ & $\mathrm{DD}$ \\
$E_{1}$ & $E_{1}$ & $4 \mathrm{Q}$ \\
$E_{2}$ & $E_{2}$ & $4 \mathrm{Q}$ \\
$E_{1}$ & $A_{1}, A_{2}$ & $\mathrm{D}+\mathrm{Q}$ \\
$E_{2}$ & $B_{1}, B_{2}$ & $\mathrm{D}+\mathrm{Q}$ \\
$E_{2}$ & $A_{1}, A_{2}$ & $3 \mathrm{Q}$ \\
$E_{1}$ & $B_{1}, B_{2}$ & $3 \mathrm{Q}$ \\
$A_{1}, A_{2}, B_{1}, B_{2}$ & $A_{1}, A_{2}, B_{1}, B_{2}$ & $2 \mathrm{Q}$ \\
\hline
\end{tabular}

$$
\Delta \lambda=0, \pm|b| k, k=\sqrt{k_{\mathrm{x}}^{2}+k_{\mathrm{y}}^{2}}
$$

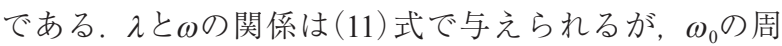
りでテイラー展開すれば,

$$
\omega_{\mathrm{k}} \approx \omega_{0} \pm \frac{|b| c^{2} k}{2 \omega_{0}}
$$

であり，等方的なディラックコーンが生じることが分か る.

\section{【例2】 $\mathrm{C}_{6 \mathrm{v}}$ 対称な2次元三角格子}

Table. 3にモードの対称性と分散曲線の形状を示す. 前述のように $\mathrm{E}_{1}$ モードと $\mathrm{E}_{2}$ モードの組合せで2重ディ ラックコーンが生じる。この場合の摂動行列を記すと

$$
C_{\mathbf{k}}^{\left(E_{1} E_{2}\right)}=\left(\begin{array}{cccc}
0 & 0 & -b k_{\mathrm{y}} & -b k_{\mathrm{x}} \\
0 & 0 & -b k_{\mathrm{x}} & b k_{\mathrm{y}} \\
-b^{*} k_{\mathrm{y}} & -b^{*} k_{\mathrm{x}} & 0 & 0 \\
-b^{*} k_{\mathrm{x}} & b^{*} k_{\mathrm{y}} & 0 & 0
\end{array}\right)
$$

であり，固有值は

$$
\Delta \lambda= \pm|b| k(\text { double roots })
$$

であることが容易に分かる.

以上の例からもわかるように, 摂動行列Cは比較的簡 単な構造をもち, 多くの行列要素がゼロである.このこ とから, 3次元系の解析も比較的容易であり, 例えば $\mathrm{O}_{\mathrm{h}}$ 対称な単純立方格子について，ディラックコーンの生成 条件が完全に判別できた7).

これまでの例では，等方的なディラックコーンが生成 する場合だけを紹介したが，偶然縮退する2つのモード の対称性の組み合わせや試料構造の対称性によっては, 異方的なディラックコーンが生成する場合もある。文献 7ではそのような例も扱った。

\section{5. おわりに}

これまで述べてきたように，対称性の適切な組合せに よって，2つの固有モードの偶然縮退を用いたディラッ 
クコーンの形成が可能である. $\boldsymbol{k} \cdot \boldsymbol{p}$ 摂動による解析を見 れば分かるように, ディラックコーンの生成では構造の 周期性と固有モードの対称性が本質的である。したがっ て, ディラックコーンの生成は電磁波に限らず, 周期構 造中の波動一般に共通した性質である。その例として, 厚みを周期的に変調した半導体量子井戸について, $\boldsymbol{k} \cdot \boldsymbol{p}$ 摂動法による解析計算と有限要素法による数值計算で調 ベたところ，電子波のディラックコーンの形成が証明で きた ${ }^{8)}$ 。フォノン， ポラリトン，マグノン等についても ディラックコーンの形成が期待できる.

歴史的には，「点の光ディラックコーンはマイクロ波 の伝送線路理論を用いて発見され, CRLH (Composite right-/left- handed）伝送線路と命名された ${ }^{9-12)}$. その後, 一般の場合が文献7で証明された。光デイラックコーン の応用として文献1に示されたクローキングや屈曲導波 路などに加えて, 光子のジグザグ運動 (Zitterbewegung) ${ }^{13)}$ や拡散的な光透過 ${ }^{14,15)}$ などの新現象も予想されている.

光波ディラックコーンの実証研究については, フォト ニック結晶スラブを用いた試料作製が複数のグループで 進行中のようであり, 近い将来に実証データが得られる ものと期待される.

\section{参考文献}

1) X. Huang, Y. Lai, Z. H. Hang, H. Zheng, and C. T. Chan: Nature Mater. 10 (2011) 582.

2) S. Matsuzawa, K. Sato, Y. Inoue, and T. Nomura: IEICE Trans. Electron. E89-C (2006) 1337.

3) K. Sakoda and H-F. Zhou: Opt. Express 18 (2010) 27371.

4）厳密に言うと, $k \neq 0$, かつ, $k \neq \pm \pi /|\mathrm{a}|$ の場合.

5) K. Sakoda: Opt. Express 20 (2012) 3898.

6) K. Sakoda: Opt. Express 20 (2012) 9925.

7) K. Sakoda: Opt. Express 20 (2012) 25181.

8) Y. Yao and K. Sakoda: to be published.

9) A. Sanada, C. Caloz, and T. Itoh: IEEE Microwave and Wireless Components Letters 14 (2004) 68.

10) A. Sanada, C. Caloz, and T. Itoh: IEEE Trans. on Microwave Theory and Techniques 52 (2004) 1252.

11) A. Lai, C. Caloz, and T. Itoh: IEEE Microwave Magazine 5 (2004) 34.

12) C. Caloz and T. Itoh: Electromagnetic Metamaterials: Transmission Line Theory and Microwave Applications (Wiley, 2005).

13) X. Zhang: Phys. Rev. Lett. 100 (2008) 113903.

14) R. A. Sepkhanov, Y. B. Bazaliy, and C. W. J. Beenakker: Phys. Rev. A 75 (2007) 063813

15) M. Diem, T. Koschny, and C. M. Soukoulis: Physica B 405 (2010) 2990. 